\title{
EVOLUTION OF THE PHILOSOPHICAL UNDERSTANDING OF THE ESSENCE OF MUSIC AS A MIRROR OF HUMAN SPIRITUALITY IN EUROPEAN CULTURE
}

Students of the specialty management of social and cultural activities should be motivated to consider the history of musical art in unison with the evolution of European philosophy. The author suggests to encourage students to study "History of Art" by using proposed the introductory lecture on "Evolution of the Philosophical Understanding of the Essence of Music as a Mirror of Human Spirituality in European Culture".

Article's purpose - to explore the evolution of philosophical understanding of the essence of music, its role in the spiritual life of a human and society in European culture (from antiquity to modernity). The methodology of the research is to use methods: Logical and historical method, Systematic approach, Structural analysis to show philosophical and musical orientations with the evolution of society. The article analyzes the evolution of the phenomenon of music by clarifying its essence and influence on human spirituality in European culture.

The author draws attention to the specifics of "theoretical" music and musical practice. Attention is focused on the role of music in society and its value attitude at turning points in the history of European culture. Much attention is paid to the essence of "theoretical" and "practical" music in ancient culture and its functions in society. The article shows the dynamics of changes in musical functions in the era of the Middle Ages and the Renaissance in connection with the ideological paradigm, which is based on the triad "God - human - music".

The author has convincingly proved the philosophical understanding of music as an expression of human feelings, that is, as an art in the modern sense of the word. Attention is focused on the antinomy of music at the turn of the XIX-XX centuries. It emphasizes the difference between the terms "music-art" and "music-non-art", their content and features. The author considers new functions of music in modern European culture: cultural and group, compensatory, cultural and identification. It would be advisable to use interdisciplinary communication with philosophy when teaching other arts in higher education institutions, which will enhance the effectiveness of training future managers of social and cultural activities in Ukraine.

Key words: manager of socio-cultural activities, antiquity, the renaissance, music, art, practical music, Middle Ages, group, theoretical music.

Олександр СОЛДАТЕНКО, orcid.org/0000-0001-7400-2779

кандидат педагогічних наук, доиент кафедри музичного мистецтва та менеджменту соиіокультурної діяльності Національного університету «Чернігівський колегіум» імені Т. Г. Шевченка (Чернігів, Україна) ssanya2012@ukr.net

\section{ЕВОЛЮЦІЯ ФІЛОСОФСЬКОГО РОЗУМІННЯ СУТНОСТІ МУЗИКИ ЯК ДЗЕРКАЛА ДУХОВНОСТІ ЛЮДИНИ В ЄВРОПЕЙСЬКІЙ КУЛЬТУРІ}

Наукова новизна статті полягає в обтрунтуванні необхідності заохочування студентів спеціальності «Менеджмент соціокультурної діяльності» до вивчення навчальної дисципліни «Історія мистецтва» через розгляд специфіки музики кожної епохи не тільки з історичної, а й з філософської точки зору, використовуючи для иього запропоновану автором вступну лекиію на тему: "Еволюиія філософського розуміння сутності музики як дзеркала духовності людини в європейській культурі».

Метою статті є дослідження еволюиії філософського розуміння сутності музики, їі ролі у духовному житті людини та суспільства в європейській культурі (від античності до сучасності). Методологія дослідження полягає у використанні логіко-історичного методу, систематичного підходу та структурного аналізу для аргументації зв'язку філософії та музики з еволюиією суспільства.

У статті проаналізовано еволюцію явища музики шляхом з'ясування ї̈ сутності та впливу на духовність людини в європейській культурі. Автор звертає увагу на специфіку «теоретичної» музики та музичної практики. Увага зосереджена на ролі музики в суспільстві та ї̈ ціннісному ставленні до переломних моментів в історії 
європейської культури. Велика увага приділяється суті «теоретичної» та «практичної» музики в античній культурі та ї̈ функиіям у суспільстві. У статті показана динаміка змін музичних функиій в епохи Середньовіччя та Відродження у зв 'язку з ідеологічною парадигмою, щзо трунтується на тріаді «Бог - людина - музика».

Автор переконливо довів філософське розуміння музики як вираження людських почуттів, тобто як мистеиттва в сучасному розумінні иъього слова. Увага зосереджена на антиномії музики на зламі XIX-XX століть. Він підкреслює різницю між термінами «музика-мистецтво» та «музика-не-мистецтвво», їх змістом та особливостями. Автор розглядає нові функиї музики в сучасній європейській культурі: культурну та групову, компенсаторну, культурну та ідентифікаиійну. На його думку, у подальших дослідженнях доцільно було б використовувати міждисииплінарний зв'язок із філософією при викладанні інших видів мистецтв у закладах вищої освіти для підвищення ефективності підготовки майбутніх менеджерів соиіокультурної діяльності в Україні.

Ключові слова: менеджер СКД, античність, відродження, музика-мистецтво, практична музика, середньовіччя, страт, теоретична музика.

Research problem. For several years I have been teaching the discipline "History of Art" for bachelors in the specialty "Management of social and cultural activities" at the T. H. Shevchenko National University "Chernihiv Colehium". At the end of the course, students receive deep and diverse knowledge of world's and European musical culture. Students, as future managers of social and cultural activities, should receive knowledge allowing them to explain to people in an accessible form what kind of music and why it was in different historical periods. However, i noticed that many students view the specifics of music in each era only from a historical point of view. That is, the reason for the change in people's musical tastes is directly related to the change in the historical era. I suggest students to look at this problem from a philosophical point of view, since it is philosophy that is designed to answer the questions "what for" and "why".

At the beginning of the 20th century, B. Asafiev wrote about the need to consider the history of musical art in unity with the evolution of the whole European culture and people's spiritual life (Асафьев, 1971). This point of view inevitably emphasizes the understanding of music as a special phenomenon, its essence at the level of interaction "culture music - spirituality of a person" in the context of the development of European philosophy.

The appeal to the philosophical substantiations of music is dictated by the fact that both philosophy and music are specific forms of the human "I" manifestation, special intellectual and spiritual systems and philosophy, as a concentrate of spiritual self-consciousness absorbs music as a form of its manifestation. In order students, while studying the discipline "History of Art", not only presented a complete picture of European musical culture, but also understood the reasons for its diversity in different eras. I read the introductory-overview lecture: "Evolution of the philosophical understanding of the essence of music as a mirror of human spirituality in European culture".
After completing the course, students write an essay in which they trace the causal relationship between changes in philosophical doctrines in each historical era and the corresponding change in the meaning, content and purpose works of art. Thus, this article not only actualizes the issue of a philosophical understanding of the relationship of music and human spirituality in European society, but may be useful in preparing future managers of social and cultural activities in Ukraine.

Analysis of recent research and publications. An analytical review of the scientific and special musical literature showed that an analysis of the phenomenon of "music" and the peculiarities of the refinement of its functions in various historical periods of European culture was carried out by: E. Vasylchenko, D. Zoltai, M. Kahan, A. Losiev, M. Tarakanov, V. Tatarkewych, V. Shestakov, V. Tsypin, V. Kholopova, T. Cherednychenko.

The study of music as a cultural phenomenon and its philosophical justifications (V. Tiurina, B. Dondokov); the role of music in the philosophical understanding of the world in European culture (A. Tormakhova (Тормахова, 2009), M. Olieinik (Олейник, 2007), O. Antonets (Антонець, 2006), T. Zhavoronkova); relationship of philosophy and music (R. Keil (Кайль, 2003), I. Zatravkina (Затравкина, 1984) presented in $\mathrm{PhD}$ and doctoral theses. At the same time, the question of the evolution of the philosophical understanding of the essence of music as a mirror of human spirituality in European culture remained outside the field of vision of the researchers.

The purpose of this publication - to analyze the evolution of philosophical understanding of the essence of music, its role in the spiritual life of a human and society in European culture (from antiquity to modernity).

Presentation of the main research material. The development of philosophical understanding of the essence of music in European culture is a clear evidence of the evolution of human spirit. Music is 
an artifact, so the understanding of its essence has changed along with cultural and historical changes in the philosophical concept of human spirituality and its place in the world. This is not only the phenomenon of the music itself, but also the musical space that it creates around itself, attracting to it all the components of the spiritual life of society and a man.

The history of the philosophical understanding of the phenomenon of music originates from antiquity and has four stages of its development, when the understanding of the essence and value of music has changed significantly: magical - with the semimythical figure of Orpheus, who quenches hellish forces by playing the lyre; mystical, when the nature of magical ecstasy changed by Pythagorean purification or catharsis; ethical - recognition of the ethical nature of musical structures; aesthetic, when musical inspiration found unlimited freedom of expression.

Pythagoras believed that musical law is primarily a material law and it manifests itself in a special "world music" - Musicamundana (Жмудь, 2012). It is followed by Musicahumana or human music, since harmony is also characteristic of a spiritual person. This is the essence of catharsis - purification of the mind from everything random, transient, and not consonant, and the acquisition of a state of supreme harmony, is one of the central concepts of the ancient Greek teaching about music.

The goal of music by Platon was to educate the ideal citizens of the ideal state, when truly spiritual, moral art became canonical, and knowledge of the benefits or harm to use structural and various melodies became the essence of the teaching on ethos. Such cause-and-effect relationship can be traced as: "music" - "etos" - "paideia".

When the ancient art passed into the aesthetic stage, the music was no longer to merge with the highest harmony and upbringing of a bold citizen, it became aesthetic pleasure. It was then, according to Aristotle, that music as the "filling of our leisure" should have serve as "the intellectual entertainments of free people" (Cvrljak, 2008). Aristotle believed that one of the main functions of music is relaxing, fun and pleasure, that is carrying out useful cultural and leisure activities.

Agreeing with M. Olieinik, it can be argued that at that time ancient music "entered the context of the triad "space - the soul of human - music", divided into two completely different areas: "theoretical" music that is "pure" science is perceived by reason and "practical", that is, sensual music" (Олейник, 2007: 6). But in the Middle Ages, music began to be understood "primarily as a science, and not as an art" (Тормахова, 2009). Now it is based on a triad: "God - the soul of human - music". Referring to Saint Augustine of Hippo's treatise "On Music", it can be argued that music at that time belonged to the field of mathematical knowledge and as such it was understood primarily as the science of numbers.

Music has retained the division into "theoretical" and "practical-sensual", giving them a different meaning. Liturgical singing to some extent corresponded to "theoretical" music. Although it performed the sacred-symbolic function and the function of preaching, was not really an art. In the early Middle Ages, John Chrysostom, Basil of Caesarea, Saint Jerome and others interpreted the influence of music on the human soul only as a tool to achieve repentance. However, later, in the tenth century, there were attempts to unite faith and feelings, morality and pleasure in music. At the same time, according to A. Tormakhova, "the problem of the musical ethos developed from the point of view of its cathartic manifestations, and the melody began to be considered as the most effective component of music, being a source of aesthetic pleasure" (Тормахова, 2009: 9).

It is known that the medieval understanding of music primarily as a science, and not as art, was influenced by Neopythagoreanism and Neoplatonism, from which the tendency to numerical symbolism and allegorical interpretation of music was based. To a new level at the same time worked out the idea of the numerical structure of the music, close connection to the music number, shape and beauty. Going to the Middle Ages was marked by the spiritual omnipotence of the Catholic Church. Art now served religion, served God. Over time, the hymns have become a promising genre of church music. Unlike choirs, the hymns were based on poetic texts, and they were specially compiled, not borrowed from the holy books.

After the hymns, new forms of "Anti-Grigorian movements" appeared sequences (IX - X centuries). In the form of improvisational-poetic inserts-episodes that adorned the old prayer text. Poetic images, expressiveness and ease song melodies made them popular in different parts of society. XII - XIII century was the era of the late European Middle Ages. Culture centers were gradually moving from the monasteries to the cities. Music was included in the number of sciences too. For a long time it was considered in the same row with Mathematics, Astronomy.

Professional worldly music in the Middle Ages in Western Europe arose later than the church music. However, it already existed in the period of early feudalism in the courts of the great masters of 
the feudal world. The knightly art of troubadours, trouveres and minnesingers in secular lyrics declared itself with unexpected strength.

During the Renaissance, according to M. Praetorius, P. Melanchthon, G. Leibniz, the music starts already exempted from the mandatorypractical purpose in society approved by the idea of its aesthetic impact on the human soul. L. Valla, Dzh. Tsarlino, N. Kuzanskyi note that at that time music was perceived as a source of aesthetic pleasure, and a vivid demonstration of a person's feelings became the main requirement for it.

That is, in the Renaissance, there was a gradual rethinking of the essence of music: it was perceived from the point of view of aesthetic nature; arose from the artistic pleasure that it brings to people; the concept of "musical art" is gradually born. Agreeing with A. Tormakhova, it should be noted that, in the Renaissance, opposite interpretations of the idea of musical ethos were also realized. On the one hand, Erasmus Roterodamus, Philip Melanchthon, Johannes Tinctoris emphasize the dependence of its content on the style, manner of performance and features of the instrumental support of the work. At the same time, Johann Kuhnau has an idea to deny the unlimited influence of music on a person's spirituality. At the new level, Johannes Kepler's philosophical arguments arise in the "music of the spheres" and in Platonic bodies, where he seeks to revive the idea of secular music, which, according to the scientist, is the aesthetic essence of the highest project of the universe (Тормахова, 2009).

The laws of harmony are the main essence of the music of the Renaissance, in which quite unusual rough and harsh sounds. The first and main indicator of the Renaissance is the desacralization of art and the formation of a powerful secular cultural life of society. The music was everywhere: on the streets, squares, in the homes of citizens, in the palaces of nobles and kings. Music, along with grammar, rhetoric and poetry, was part of the so-called "human sciences". Most of it was in the role of moral education of society.

In the Renaissance spiritual music kept the main themes of medieval music: praise the Lord and the Creator of the world, holiness and purity of religious feelings. Enlightenment was the final stage of formation of ideological presuppositions philosophy of music. Assessing the significance of the Enlightenment in the development of European musical culture, T. Livanova emphasizes: "This is the era of the birth of the main musical concepts in fact already secular figurative content when the music rose to the level of other arts" (Ливанова, 1983: 5). Jean-Jacques Rousseau noted that the "naturalness" of music now lies in the true reflection of human spirituality.

At the present time, according to A. Tormakhova, "preliminary ideas about musical art are changing: the concept of ethos, according to Herder, is transformed into the idea of education by folklore, which is achieved by his general understanding and mimesis theory. It is being updated, which is currently associated with an imitation of the inner world of an individual" (Тормахова, 2009: 10).

The period of classicism in European music was divided into a part of the 18th century and a part of the 19th century. With the establishment of classical German philosophy, a new understanding of music as an expression of human feelings, it becomes art in the modern sense of the word. Already there is talk about the philosophy of music as an independent sphere of comprehension of the human being. In the second half of the XIX century, musical art, according to A. Schopenhauer, is considered superior to science, according to F. Nietzsche, has a transforming power and, according to the concept of R. Wagner, will be able to fill life with the meaning and unity of a nation. Music acquires an individual-personal character, the main thing in it is not exemplary, but originality.

Agreeing with T. Adorno, it can be stated that in the XX century the essence of music is increasingly seen in the formation of human spirituality. Starting from the new European romanticism, "practical" (secular) music has become a powerful means of spiritual selfexpression of the individual and the theory of musical art has taken the place of "theoretical" music. A kind of "reflection of music above oneself" was expressed in the idea of the living unity of the composer's feelings and their embodiment in sounds (Адорно, 2001).

As is known, that in Europe at the turn of the XIX - XX centuries there was a division of musical art into "art" and "non-art". It was concretized in the allocation of two musical directions: "serious" "professional" and "light" - "mass". A sign of "art" is the aesthetic value of the works. On the contrary, music in the form of "non-art" exists for entertainment purposes, that is, for the disclosure of human emotions. Despite the decline in public demand for musical art, it performs all the same functions that were inherent in it in antiquity, that is, it frees the soul from the evil generated by affects that are not cultivated by opinion.

Music in the form of "non-art" also performs many functions: expands the sphere of the unconscious; frees human from the moral and ethical imperatives pressure; supports in the souls of people aggressive destructive pathos; gives a peculiar therapeutic effect; draws the individual into the elements of the 
collective unconscious, you can compare musical performances, which are collected a huge number of fans, the audience, with the transformation of the forms of initiation.

Since the second half of the XX century music "non-art" begins to give rise to the phenomenon of social stratification, especially among young people. The educational role of music is now localized within one or another stratum, and its impact on the emotions and affects of a person acquires a huge range: from "soft", mediated to "hard", aggressive. In fact, we are talking about compensatory functions of music, when it, becoming a form of a certain virtual reality, forms around itself a new socio-cultural space, compensating a person for the lack of a comfortable spiritual life in real society. In the creative process of the musical culture of the twentieth century, there are tendencies to synthesis, purposeful or random combination of isolated, integral styles, generalization, brevity, and, at the same time, a plurality of musical expression.

In the European musical culture of the twentieth century there are common features in the development of leading art trends, such as: impressionism, expressionism, folklore studies, neoclassicism, which was formed at the beginning of the century from the point of view of pluralism artistic phenomena. In the second half of the twentieth century, with pronounced post or neo features, they give rise to specific synthetic or poly-stylistic phenomena that adapt to new style conditions, new ways of organizing sound material using new composition methods such as: serialism, sonoristics, aleatory, specific and electronic music, etc.

At the end of the 20th century, the role of mass music in releasing human affects immeasurably increases, which pushes "musical art" to the cultural periphery. Due to the inaccessibility of the educational impact of "high music" on the spirituality of the population as a whole, it cannot serve as a criterion for cultural identification in modern society.

On the role of such a criterion, in our opinion, today claims authentic folk music as a source of cultural unity of civil society. First, folklore is both "art" and "non-art", performing together aesthetic, artistic and utilitarian functions. Secondly, it is an example of a harmonious form of communication between people through: joint listening; coordinated movement; the joint creation of a social group united by a common national-intonation thinking, in which the social and communicative function of music is manifested.

Conclusion and prospects for further research. Thus, we can conclude that the evolution of the philosophical understanding of the essence of music as a mirror of human spirituality in European culture has been formed over a long period. From the philosophical and aesthetic heritage of antiquity to the 20th century there were attempts to explain the phenomenon of music, to determine its place in the spiritual life of man and society. In the era of Antiquity, a distinction was made between the theoretical and practical spheres of music and the emergence of a new subject of philosophical thinking within the framework of the Pythagorean eurythmy theory and the magically healing properties of music (canonics), Aristotle's mimesis.

In the Middle Ages, the main functions of music are: the development of ethical qualities, the achievement of piety, moral education. Music is understood as a reflection of world harmony. It acts as a means of attracting a person to true being and is the embodiment of the magic power of numbers.

The Renaissance is characterized by a tendency towards the de-sacralization ofmusic and the formation of an anthropological interpretation of secular music, which changes the meaning of its educational, pedagogical, therapeutic and social functions. In the era of the Enlightenment, the old notions of musical art change: the concept of ethos is transformed into the idea of education through folklore; the theory of mimesis has been updated, which is now connected with the imitation of the inner spiritual world of an individual; notes the presence of meaning in music.

A characteristic feature of the "classical" period of the philosophy of music of the XIX - XX centuries is a tendency to intensify the synthesis between the types of musical art, which contributes to the expansion of their possibilities of spiritual education both among the public and among the performers.

Also, in our opinion, in European tradition of understanding the essence of music, there was a kind of antinomy: in the era of antiquity, this division of music into "theoretical" follows the harmony of the cosmos and "practical", which is a weak copy of this imitation. Then, in the European Middle Ages, this is the opposition of music (purely practical, "human") and singing. Finally, starting from the Renaissance, "practical" music becomes an area of human spiritual expression in art, and music theory "serves" the composer and performs musical practice. In the XX century anti comicality of understanding was manifested inside "practical" music, which the researchers divided into "art" and "non-art".

In our opinion, it would be advisable to use interdisciplinary communication with philosophy when teaching other arts in higher education institutions, which will enhance the effectiveness of training future managers of social and cultural activities art in Ukraine. 


\section{BIBLIOGRAPHY}

1. Адорно Теодор. Философия новой музыки. Москва, 2001. 343 с.

2. Антонець О. А. Еволюція салонної музики в європейській культурі : дис. канд. мистецтвознавства: 17.00 .03 / Сумський держ. педагогічний ун-т ім. А. С. Макаренко. Суми, 2006. 244 с.

3. Асафьев Б. В. Музыкальная форма как процесс. Ленинград, 1971. 376 с.

4. Жмудь Л. Я. Пифагор и ранние пифагорейцы. М., 2012. 445 с. ISBN 978-5-91244-068-7.

5. Затравкина И. А. Проблемы музыки в немецкой идеалистической философии конца XVIII - XIX века : дис. канд. филос. наук: 09.00.04 / Марксистско-ленинская естетика. Москва, 1984. 157 с.

6. Кайль Р. Р. Проблема взаимосвязи философии и музыки: на материале творчества Фридриха Ницше и Рихарда Вагнера : дис. канд. филос. наук: 09.00.04 / Моск. гос. ун-т сервиса. Москва, 2003. 123 с.

7. Ливанова Т. Н. История западноевропейской музыки до 1789 года. Москва, 1983. 2 том. 622 с.

8. Олейник М. А. Функции музыки в европейской культуре: философско-антропологический аспект : дис. доктора филос. наук: 09.00.13 / Юж. федер. ун-т. Ростов-на-Дону, 2007. 305 с.

9. Тормахова А. М. Філософія музики в контексті європейської музичної культури XIX - XX ст. : автореф. дис. канд. філос. наук. Київ, 2009. 16 с.

10. Cvrljak Kresimir. Aristotel o vglazbeno-teorijskispis, ARMUD6, 39/2 (2008). P. 179-218.

\section{REFERENCES}

1. Adorno Teodor: Filosofiya novoy muzyiki [Philosophy of New Music]. Moscow : Logos, 2001, 343 [in Russian].

2. Antonets E. A. Evolyuciya salonnoyi muziki v yevropejskijkulturi [The evolution of salon music in European culture] (PhD Thesis). Sumy : B.v., 2006, 244 [in Ukrainian].

3. Asafiev B. V. Muzykalnaya forma kak process [Musical form as a process]. Leningrad : "Muzyka", 1971,376 [in Russian].

4. Zhmud L. Y. Pifagor i ranniepifagorejcy [Pythagoras and the early Pythagoreans]. Moscow : Un-t D. Pozharskogo, 2012, 445. ISBN 978-5-91244-068-7 [in Croatian].

5. Zatravkina I. A. Problemy muzyki v nemeckoj idealisticheskoj filosofii konca XVIII - XIX veka [Problems of music in the German idealistic philosophy of the end of the XVIII - XIX centuries] (PhD Thesis). Moscow, 1984, 157 [in Russian].

6. Keil R. R. Problema vzaimosvyazi filosofii i muzyki: na material tvorchestva Fridriha Nicshei Riharda Vagnera [The problem of the interrelation of philosophy and music: based on the work of Friedrich Nietzsche and Richard Wagner] (PhD Thesis). Moscow, 2003, 123 [in Russian].

7. Livanova T. N. Istoriya zapadnoevropejskoj muzyki do 1789 goda [History of Western European music until 1789]. Moscow : Muzyka, 1983, vol. 2, 622 [in Russian].

8. Olieinik M. A. Funkcii muzyki v evropejskoj kulture: filosofsko-antropologicheskij aspect [Functions of music in European culture: the philosophical and anthropological aspect] (PhD Thesis). Rostov-on-Don, 2007, 305 [in Russian].

9. Tormakhova A. N. Filosofiya muziki v kontekste yevropejskoyi muzichnoyi kulturi XIX - XX st. [Philosophy of music in the context of the European musical culture of the nineteenth and twentieth centuries] (PhD Thesis). Kyiv : B.v., 2009, 16 [in Ukrainian].

10. Cvrljak Kresimir. Aristotel o vglazbeno-teorijskispis [Aristotle on the musical-theoretical writing]. ARMUD6, 39/2 (2008). P. 179-218 [in Croatian]. 